\title{
N. Rózsa Erzsébet - Hagyomány és modernitás. Az iráni külpolitika kihívásai a 21. század elején
}

\section{A Nemzeti Közszolgálati Egyetem saját kiadása, Budapest, 2020}

Napjaink globalizált, sokszínű világában rendkívül fontos, hogy alapműveltségünket gyarapítva megismerjük más, nem európai kultúrák különböző aspektusait. Az itt bemutatandó mű azonban az Iráni Iszlám Köztársaság jellemzőit olyan módon elemzi, amelynek megértéséhez kellő alapismeret és érdeklődés szükséges. Habár manapság egyre nagyobb az igény a „keleti világgal” összefüggő ismeretek iránt, a mü speciális jellege miatt inkább a történelemtudományok, társadalomtudományok, hadtudományok, politikatudományok iránt érdeklődők számára lehet hasznos. Emellett alapmunkaként szolgálhat a KözelKeletet, az iszlám világot és az iszlám kultúrát vizsgáló hallgatók számára.

A szerző kiemelkedő szakértője a mü témáját képező térségnek, kutatási területei közé tartozik Irán, a Közel-Kelet társadalmi, politikai és biztonságpolitikai folyamatai, valamint a Perzsa-/Arab-öböl térsége, miáltal szakmai hozzáértése és hitelessége megkérdöjelezhetetlen. A bibliográfia 16 oldalt tesz ki, tartalmaz szakirodalmi forrásokat és hiteles internetes forrásokat (elektronikus müveket) is, amely bizonyítja, hogy a kötet naprakész információkra támaszkodik. Egy ilyen témaválasztás esetében elengedhetetlen, hogy a szerző több nyelven olvasson: a magyar nyelvü irodalmon túl számos angol nyelvü forrást is felhasznált. Ugyanakkor N. Rózsa Erzsébet az angol nyelv mellett a térség két alapvető nyelvét is felsőfokon ismeri - az arab és perzsa nyelvismeret nemcsak a tágabb forrásanyag feldolgozására ad lehetőséget számára, de ebből fakadóan az arab és perzsa világ szemszögéből is megismert és vizsgált bizonyos problémákat.

Müvében a szerző először bemutatja Irán vallási, nemzeti identitását, megfogalmazza az úgynevezett „irániság” jellemzőit. A hosszú történelmi és társadalmi adottságokat vizsgáló leírás alapos előkészítésként szolgál a „regionális hatalmiság és külpolitika” cím alatt írt elemzéshez, amely többek között az ország nukleáris programját mutatja be, megvizsgálva annak előzményeit, körülményeit. Végül a Trump-elnökség kihívásait vizsgálja, többek között az Iráni külpolitikával és a nukleáris megállapodással kapcsolatban. A könyv szerkezete kitűnően áttekinthetö. Több nagy egységre vagy fejezetre oszlik, amelyek további alfejezetekre tagozódnak, így az olvasók számára akkor is egyszerüen használható, amennyiben konkrét kérdésre keresik benne a választ. A bevezetésben (csupán két oldalban) rendkívül lényegre törően és mégis részletgazdag módon mutatja be a jelenlegi Irán legfontosabb történelmi jellemzőit, amely a modern ország megértéséhez elengedhetetlen. Irán az ókorig visszanyúló államisággal rendelkező regionális hatalom, amelynek

Bosnyák Henrietta a Nemzeti Közszolgálati Egyetem Hadtudományi Doktori Iskola doktori hallgatója. E-mail: henrietta.bosnyak@gmail.com 
három alkotóeleme az „irániság”, a síta iszlám és a modernizáció. Az Iszlám Köztársaság az 1979-es iszlám forradalmat követően alakult ki Khomeini ajatollah vezetésével, az általa kidolgozott (síita) iszlám kormányzás, a velájat-e faqíh elv alapján, amely máig meghatározza az iráni politikai (és vallási) vezetést. Célja saját forradalmi ideológiájának terjesztése volt. A bevezetés érintőlegesen utal a Pahlavi-korra, az iraki háborúra, az arab tavasz eseményeire és az Iszlám Állam elleni harcra, valamint Donald Trump elnökségére is. Ezen témakörök megismerése mind hozzájárul a nukleáris program, illetve az arra válaszul született szankciók megértéshez. Ennek ismeretében tudjuk vizsgálni az ország regionális hatalmi státuszának helyét és szerepét.

Az első fejezet tartalmában folytatja a fö téma bevezetését. Részletesen bemutatja Irán népességét, a síita iszlámot és az iráni identitást. Továbbá ismerteti az iráni történelem téma szempontjából releváns időszakait, a modernizációt szorgalmazó Pahlavi-korszakot, és az azt megállító, teokráciát előkészítő iszlám forradalmat. Az alapvető vallási és politikai információk mellett a mü még az ország irodalmi örökségébe is betekintést enged (ami alapjaiban függ össze a nemzeti identitással), megemlíti a Sáhnámét, azaz a Királyok könyvét, amely az iráni identitás alapműve (az iráni őstörténet). Ezekkel az utalásokkal (akár irodalmi, vallási, politikai) és a szakkifejezésekkel (mint egyfajta ajánlásokkal) lehetővé teszi az olvasó számára, hogy a részleteknek utánajárva a témában további ismeretekre tegyen szert. A 23. oldalon lévő ábra bemutatja az Iráni Iszlám Köztársaság müködési modelljét (saját szerkesztés szerint), amely segít az állam és a velájat-e faqíh elv megértésében, amit persze a szövegben részletesen is magyaráz. Az Iszlám Köztársaság fegyveres ereje és biztonsági apparátusa, a velájat-e faqîh modelljének fenntartásáért müködik. A szerző rámutat az ebben rejlő kettősségre: a reguláris hadsereg mellett egyfajta ideologikus fegyveres erőként működik a Forradalmi Gárda, és annak része a külpolitikai szárnyaként működő, a Qudsz Erők és a rezsim legitimálását biztosító Baszídzs Milícia.

Irán kisebbségeinek vizsgálata rendkívül fontos, hiszen közvetlen szomszédsága meglehetős sokszínűséget mutat mind vallási, mind etnikai tekintetben. Főként vallási szemszögből fontos a vizsgálat, hiszen a köztársaság nevéből adódóan is iszlám jellegü, így sajátos módon kezeli a vallási kisebbségeket. Emellett etnikai jellemzői is kivételes fontosságúak - a kurdok határokon átnyúló közösséget alkotnak a térségben, a kurd kérdéskör, avagy egy önálló Kurdisztán megteremtése nem csak Irán számára kritikus kérdés. Az ország szomszédjainak vizsgálata szintén alapvető fontosságú - például az arab-perzsa (vagy akár siita-szunnita) ellentéteket illetően, ennek ismerete fontos például a forradalomexport kérdésének, illetve Teherán Irakkal folytatott háborújának megértéséhez. Szaddám Huszein rendszerének megdöntése például egyenesen fordulópont volt Irán számára, az utóbbi években pedig az Iszlám Állam mint terrorhálózat, közvetetten bár, de fenyegetést jelentett számára. Irak mellett a legfontosabb szomszéd, amelyet elemezni szükséges természetesen Afganisztán. A közös történelem, számos hagyomány és kulturális tényező (például a közös nyelv) szintén összeköti Iránnal. A regionális külpolitikát érintő kérdésekben talán a legfontosabb megállapítás az, hogy „Ma a közel-keleti regionális politika leginkább egy hidegháborúként értelmezhető, melyben Irán és Szaúd-Arábia a föszereplők". Ezt az állítását a szerző természetesen részletesen kifejti, amely bevezeti a nukleáris megállapodás előtt uralkodó hangulatot a térségben és azon túl. Irán nagyhatalmakkal szembeni magatartását 
alapvetően a távolságtartás és függetlenség határozza meg. „A 21. században nukleáris programja miatt Irán ismételten - immár nemzetközi szankciók által - elszigetelödött. Habár 2015-től a megállapodást követően úgy tűnt nemzetközi közösség tagjaként térhet vissza, Donald Trump hivatalba lépésével Iránt ismét az elszigetelődés fenyegeti."

A szerző taglalja Irán kapcsolatait a nagyhatalmakkal, elsősorban az orosz/szovjet és brit birodalmakhoz füződő kapcsolatait, majd az Egyesült Államokhoz és az Európai Unióhoz füződő viszonyát, valamint ehhez kapcsolódóan elemzi az iráni-amerikai-izraeli háromszöget is, valamint Kína és Irán kapcsolatrendszerét. A nukleáris program megítélését a 77. oldalon kezdi tárgyalni, elemzi, hogy az iráni nukleáris vitában Kína, az Egyesült Államok és az Európai Unió hogyan foglalnak állást. Irán nemzetközi szervezetekben elfoglalt tagságának vizsgálata szintén rendkívül fontos, hiszen az ENSZ Biztonsági Tanácsa elfogadta a 2015-ös nukleáris megállapodást, így amennyiben az ország teljesíti az abban foglalt kötelezettségeit, elméletben ismét élvezheti a tagállamok nyílt támogatását egyes felmerülö vitás kérdésekben.

A következőkben a nukleáris programról és annak „történetéről” van szó. A pontos háttérinformációk alapján a szerző bemutatja mi vezetett odáig, hogy kötelező szankciók lettek kiszabva Iránnal szemben, ismerteti az átfogó nukleáris megállapodás körülményeit, tematikáját, fogadtatását és a nukleáris vita egyedi sajátosságait. Végül a szerző az utolsó fejezetben kifejti, hogyan változtatta meg az iráni külpolitika mozgásterét és a nukleáris megállapodást Donald Trump, akit 2016-ban az Egyesült Államok elnökének választottak meg. Trump Iránt igen nehéz helyzetbe hozta, a nukleáris megállapodást tulajdonképpen megvétózta. Országának kilépését az alkuból 2018-ban jelentette be. Ez a fejezet röviden, de minden fontos részletet megemlítve mutatja be Trump álláspontját, és a kilépésének hatásait.

„Egy ilyen ősi államisággal és civilizációval rendelkező ország története, irodalma, müvészete, valamint a vonatkozó szakirodalom ismertetése azonban természetszerüleg meghaladná a kötet terjedelmét, ezért itt ezekre csak annyiban térünk ki, amennyiben az a mai kérdések jobb bemutatásához, megértéséhez szükséges.”2 Ezzel a mondatával a bevezetésben a szerző maga is utal arra a tényre, hogy a mü pontos megértéséhez alapos háttérismeretekre van szüksége az olvasónak. A müben az arab és perzsa nyelvű szavak kiejtés szerint lettek átírva. Habár a kiolvasásuk így a nyelvtudással nem rendelkezők számára egyszerübb, más szakirodalmi müvekben gyakran használják a tudományos betüátírási formákat is, amelyek pontosabban jelölik a kiejtést, és az idegen nyelvben leírt betüket is pontosan jelölik. Mivel az ilyen jellegü elemzések föként hozzáértő olvasóknak készülnek, alkalmazható lenne a pontosabb megértést szolgáló tudományos átírás is. Mindemellett a kötetben olvasott információk és összefüggések megismerése elengedhetetlen ahhoz, hogy megértsük a mai Irán regionális kihívásait, kül- és belpolitikai ambícióit, így bizonyossággal állítható, hogy a mü alapvető olvasmánya a Közel-Kelettel, illetve a Perzsa-öböllel foglalkozó kutatóknak és laikus érdeklődőknek egyaránt.

N. Rózsa Erzsébet: Hagyomány és modernitás. Az iráni külpolitika kihívásai a 21. század elején. Budapest, Nemzeti Közszolgálati Egyetem, 2020. 7. 